\title{
Q\&A
}

\section{Bengt Wahlström}

\section{Q. What Can Action Research Learn from Business Environment Analysis?}

\begin{abstract}
A ing point for bridging the divide between academia and business, because action research does not accept the boundaries between the researcher and what is being researched and it seeks to bring in other types of knowledge fields. But there is a group that has long worked in the borderland between academia and practice: consultants. They already use and create theories in their quest to help organizations develop, and in my own 30 years as a consultant within business environment analysis, I have seen how insights from consultancy can help bridge the divide between academia and business. But, before answering what action research can learn from business environment analysis, an overview of each field is in order.
\end{abstract}

\section{Business Environment Analysis}

Business environment analysis is used to identify strategically relevant external and internal factors, both expected and unexpected, that can affect an organization's performance. Hence, business environment analysis, broadly speaking, is the process of interpreting signals from outside the firm and then through insights gained through this analysis - changing the company's operation and strategic intent to make the organization more viable.

Monitoring the outside world is a matter of survival for any organization. Argyris and Schön (1996) argue that everyone - from companies and organizations to regions and nations - must adapt to changes in the outside world and learn from others' successes and failures, as well as discover challenges and threats while watching what is happening. Hamrefors (2002) adds that observing and analyzing these signals are not enough. Without action, companies will lag behind the competition. The implementation of effective business environment analysis systems and processes helps organizations to go from signals, through to the analysis, and then to taking appropriate actions.

Pfeffer and Salancik (2003) divide the outside world into several levels. One level consists of the actors and activities outside the organization but with links to the business in question. Another level is the different actors that the organization interacts with, and a third level is how the organization itself perceives and interprets this outside world (see also Hoppe, 2009). In this sense, a business environment analysis consultant assists their clients in the process of discovering, interpreting, and taking advantage of various business environment changes at all these levels.

The interest in using business environment analysis has increased significantly over the years, which is in line with the ever faster and more dramatic changes occurring in the world. However, the link between these changes and the organization's activities is not always obvious. Rohrbeck and Gemünden (2011) note that a rapid development rate - where there are increasing numbers of innovations, unexpected technology shifts, and shorter product lifecycles - creates difficulties in adapting, and thus capturing, business environment information.

\section{Linking Action Research to Management and Consultancy Work}

The concept of action research was coined by Kurt Lewin (1946) to describe a problem-solving mechanism where researchers would engage in the emancipation of underprivileged groups by helping them research their own situation and future. Over the years, the concept of action research has developed and gained many different meanings in addition to Lewin's connection to social action and minority problems. Johansson and Lindhult (2008) argue that the term is now used in so many ways that it has lost its original meaning. They emphasize the concepts of pragmatic versus critical orientation of action research and note that, in Scandinavia, the pragmatic orientation is strong. It is characterized by a broad and open dialogue between everyone involved and where the researchers are partners in this dialogue. The researcher's role, among other things, is to support the concrete knowledgebuilding, which at the same time includes practice development. 


\section{Q\&A. What Can Action Research Learn from Business Environment Analysis?} Bengt Wahlström

In line with the conceptual shift that Johansson and Lindhult (2008) point to, action research has increasingly come to be used in management. French (2009) makes a comprehensive review of the literature concerning action research in connection with management and lists a number of arguments why action research is a methodology that fits practicing managers. Some examples are:

\section{"Action research integrates thought and action, allows practitioners to research their own profes- sional activities, improve practice at the workplace and helps managers to be multidisciplinary and work across technical, cultural and functional boundaries. It is also problem-focused, context specific and future-oriented." (French, 2009)}

French (2009) also summarizes, based on his literature review, the work with action research in a four-stage, spiral model: 1) develop a plan, 2) act to implement the plan, 3) observe the action and collect data, and 4) reflect on the action and re-plan.

Gummesson (2000) lists several action research characteristics that are relevant to management such that action research strives for holistic understanding and recognizes complexity. Furthermore, action research is useful when it comes to understanding, planning, and implementing change processes in companies and organizations. Coughlan and Coghlan (2002) use Gummesson (2000) to explain the difference between action research and consulting. Consultants working with action research need to be more thorough with surveys and documentation than in their usual consulting work. Compared with an action researcher, a consultant is used to working under greater limitations when it comes to time and budget. The consulting work is often linear: the consultant engages, analyzes, acts, and disengages. Action research, on the other hand, is cyclical and consists of data collection, feedback, data analysis, planning, acting, evaluating and then continuing to collect new data, etc.

An academic with a strong consultancy agenda is Kaplan, who in 1998 launched a special form of action research called "innovation action research", which is about researchers actively participating in helping organizations implement new ideas. According to Kaplan, a consultant/researcher helps the client focus on and test an emerging theory that could improve the organization's performance.

\section{Empirical Findings from Decades of Consulting}

For over 30 years, I have worked with over 400 different clients and held more than 2,500 seminars and lectures about business environment analysis. The knowledge structure of the assignments can be divided into several different categories, depending on the client's wishes and on the client's maturity level regarding the use of business environment analysis. The assignments also differ in length, from one-hour lectures to year-long collaborations. Single, short lectures and seminars, whose main purpose is to go over current trends and position these trends in relation to the client's business, are the most common. In other assignments, the goal is to teach the client certain methods and tools so that the client can develop their own business environment analysis on a regular basis. A third category of assignments are reports and investigations, where business environment analysis, including both expected and unexpected trends, is used to highlight a particular theme associated with the client's business. Some clients demand digital platforms that are filled with business environment analysis signals on a regular basis. As a consultant, I listen to the client's knowledge needs and adjust the delivery of the content to these needs. I also have written books that summarize new developments in business environment analysis, which can be related to Kaplan's (1998) descriptions of how more general knowledge from consultancy work is gathered and disseminated to a broader audience.

My work as a consultant means working with several parallel knowledge structures, each with different purposes and recipients. These knowledge structures can be divided into some main areas, such as content, method, presentation, and technology. Depending on the nature of the assignment, different parts of the knowledge structures are handled in parallel. Another type of parallel knowledge structure is that acquired knowledge that deals with my own practice can be directly translated into changed actions, while acquired knowledge of a client's business first may need some internal explanation before it can be useful.

Thus, the knowledge structures for different business environment analysis assignments vary according to the nature of these assignments, as shown in Table 1. 


\section{Q\&A. What Can Action Research Learn from Business Environment Analysis? Bengt Wahlström}

Table 1. Knowledge structures for different types of business environment analysis assignments

\begin{tabular}{|c|c|}
\hline Assignment & Knowledge Structures \\
\hline \multirow[t]{3}{*}{ Seminars } & $\begin{array}{l}\text { - Content (current, forward-looking trends, including "Black Swans”, that is, unexpected trends) } \\
\text { (Taleb, 2008) }\end{array}$ \\
\hline & - $\quad$ Method (overview) \\
\hline & - Presentation technology (advanced digital slideshows) \\
\hline \multirow[t]{3}{*}{ Education } & - Method (in-depth review) \\
\hline & - Pedagogy (examples, learning from others) \\
\hline & - Presentation technique (basic, digital slideshow) \\
\hline Reports & - Content (focus on special topics, complemented with business environment analysis) \\
\hline \multirow[t]{2}{*}{ Investigations } & - Analysis (draw conclusions, make checklists, and suggest decisions and actions) \\
\hline & - Presentation (make the content accessible and comprehensible) \\
\hline \multirow[t]{4}{*}{ Digital platform } & - Technology (building the digital platform) \\
\hline & - Layout (make the portal's interface accessible) \\
\hline & - Content (fill the portal with relevant business environment analysis signals) \\
\hline & - Analysis (draw conclusions from the business environment analysis signals for decisions and actions) \\
\hline \multirow[t]{3}{*}{ Books } & - Content (long perspective, forward- and backward-looking) \\
\hline & - Narrative (coherent story through the book) \\
\hline & - Presentation (accessible, with summaries and oversized quotations) \\
\hline
\end{tabular}

When it comes to business environment analysis, the organization's knowledge needs are different for different actors within the organization, such as the person who orders the assignment, the organization's employees, and the project's external target groups. In the organizations I have worked with, there are often different groups with different agendas, goals, knowledge, and so forth. This creates a particularly challenging environment for anyone who wants to work with action research for organizational development purposes since there are almost always shared opinions about the goal and approach for a possible action research project. This reality also differs from many other versions of action research, which has significantly clearer and more homogeneous groups to work with, for example, underprivileged groups in vulnerable areas.

The potential client's understanding of the importance of business environment analysis is often lacking, hence, the business environment analysis must be made interesting, for example, by presenting signals that are so exciting that they become eye-openers, leading to further discussions. The participants can be extremely knowledgeable in their respective fields but may not have much knowledge about how unexpected and disruptive events in the outside world would affect the company. This means that the knowledge needs also vary depending on the nature of the assignments, as shown in Table 2.

Examples of the combination of action research and business environment analysis

All types of assignments, from short seminars to yearlong collaborations, contain different knowledge structures and knowledge needs with links to action research. These links between business environment consultancy work and action research are, however, easiest to discover in the longer assignments. The participation takes place in different ways, depending on the situated conditions, as the following client examples show: 


\section{Q\&A. What Can Action Research Learn from Business Environment Analysis? Bengt Wahlström}

Table 2. Examples of knowledge needs for different actors

\begin{tabular}{lll}
\hline Actors & Examples of Knowledge Needs \\
\hline $\begin{array}{l}\text { The person who orders } \\
\text { the assignment }\end{array}$ & - & Learn to understand the overall meaning of business environment analysis for their own organization \\
& - & Learn to see the link between business environment analysis and the organization's core business \\
\hline The organization's & - Learn the methods of business environment analysis \\
employees & - Learn how to work with a digital portal \\
& - Learn to work in a digital way at a more general level \\
\hline $\begin{array}{l}\text { The project's external } \\
\text { target groups }\end{array}$ & - Learn to better understand the outside world \\
\hline
\end{tabular}

1. A labour market organization ordered a business environment analysis education project that gave regular feedback from the client's employees. They used the tools in the project with their customers and reported how it worked. This information was then used to continuously develop the material.

2. A region ordered a business environment portal online but was not specifically involved in the project. They let it continue, as business environment analysis was considered necessary in some form. The participation was indirect and consisted of the business environment consultant being able to follow and analyze how the business environment analysis portal was used and then both content and function were developed in accordance with user behaviour.

3. A member organization ordered both an online portal and seminars. The manager encouraged the project and ensured that the users participated and gave continuous feedback. The result was continuous changes that adapted the project to the users' knowledge needs, for example, by moving from a business environment analysis portal to a newsletter and thereby improving the usability.

4. A transport sector company first bought a small business environment analysis education project, which, after the evaluation, grew into an in-depth project. Participation took place through feedback at various meetings and workshops to continuously developed the project.
The examples above clearly illustrate the difference between action research and consulting that Coughlan and Coghlan (2002) described. Consulting is linear whereas action research is cyclical and requires thorough surveys and documentation. In the examples above, there was no time for that kind of accuracy. Similarly, the four-step model described by French (2009) with its careful planning, data collection, reflecting, and re-planning - is not always something that can be used in the business environment analysis consultant's everyday life. However, Johansson and Lindhult's (2008) description of the researchers' role in supporting concrete knowledge-building can also be relevant in a consulting role. The same goes for Kaplan's (1998) innovation action research cycle. The conclusion is that, in some respects, it is reasonable to call my business environment analysis consultancy work action research, but there are differences that are interesting and that can add useful insights.

\section{What Action Research Can Learn from Business Environment Analysis}

With the literature overview, the examples, and my other experiences as a business environment analysis consultant as starting points, I have identified four insights about action research in connection to business environment analysis consultancy work, as described below. 


\title{
Q\&A. What Can Action Research Learn from Business Environment Analysis?
}

\author{
Bengt Wahlström
}

\section{Insight 1: The importance of the client's position in the organization}

Making a business environment analysis project a success is a challenge because the client's organization rarely has identified business environment analysis as business critical; business environment analysis is expected to primarily bring complementary skills. Therefore, it does matter who orders a business environment analysis project. The higher up in the organization the contact is, the greater the probability is that the project will be a success.

Contacts can come from three levels: top management, middle management, or individual employees. If the client is a top manager, the project automatically is set up with good conditions. However, problems may arise if the CEO orders the project but delegates implementation to a middle manager without stating why the project is needed. Then, there is the risk that the project will fade out and become largely irrelevant (like with the second example, the region).

The most common client is an interested middle manager who has received clearance from the CEO, who is either positive or uninterested. These business environment analysis projects are the easiest to operate successfully (like the example with the member organization above).

The business environment analysis projects with the greatest risk of failure are those ordered by an individual employee. He or she works, for example, in a development department, education department, marketing department, or human resources department. This type of project requires a purposeful anchoring process so that both middle management and top management are informed and positive or, at the very least, neutral. It is easier for individual employees to both anchor and successfully implement a business environment analysis project in a decentralized organization where many employees can act on their own (Brunson, 2006).

This practice differs from Kaplan (1998) who writes, "My personal journey started in the early 1980s, after several discussion with senior skilled managers...". Kaplan seems to have constant access to senior managers in major companies, and it is within these companies that their new ideas and innovations are tested. The reality for the consultancy work that I represent is different. In Sweden, small and medium-sized enterprises with up to 250 employees represent $99 \%$ of all companies and, in that group, the client's position in the organization is important.
French (2009) and Coughlan and Coghlan (2002) are not as clear as Kaplan (1998), but their models also seem to be based on an unproblematic relationship with the management of the participating organization.

\section{Insight 2: The importance of working with parallel knowledge structures}

Different business environment analysis projects address different knowledge structures. The seminars attempt to capture current trends, whereas the training assignments focus on methods and tools. The reports, investigations, and digital platforms almost always begin with the client's core business, which is then placed in relation to the outside world. In terms of the content, business environment analysis projects work with further parallel knowledge structures in the form of expected and unexpected trends and signals.

Hence, as a business environment analysis consultant, I must constantly work with parallel knowledge structures. A special challenge is to get the client to accept and analyze both expected and unexpected business environment trends and signals in parallel, where the unexpected trends often are perceived as disturbing.

Parallel knowledge structures can also mean that knowledge is developed by one group of participants, but another group coming later in the project will get the benefits. If we return to Kaplan (1998) for a comparison, Kaplan enters a company with a project focusing on a specific and clear knowledge structure, such as a balanced scorecard or activity-based costing.

\section{Insight 3: The importance of finding the client's different} knowledge needs

In my experience, many companies regard the outside world as somewhat diffuse and troublesome. Most companies are satisfied with monitoring Porter's (1980) five forces (competitors, customers, suppliers, substitutes, and new entrants); this means that the demand for additional business environment analysis activities is limited. Therefore, as a consultant, I must first identify the client's different knowledge needs that go beyond these five forces and then obtain acceptance of this description of reality so that it is possible to start a business environment analysis project. The easiest way to do this is by highlighting specific examples - mainly in globalization, digital transformation, or sustainable development - and linking these examples to the company's operations. Some examples include the following: How would the client be affected if were a full-scale trade war between the United States and China? What would it mean for a retail client if Amazon were to establish 


\section{Q\&A. What Can Action Research Learn from Business Environment Analysis?} Bengt Wahlström

themselves in their country? What effects would there be for the client if customers with climate change panic were to abstain from eating meat or refrain from flying in planes or buying cars? And, above all, what knowledge needs do these changes in the outside world lead to? By asking these kinds of questions, a potential client may become interested, and it is then possible to start a project.

Kaplan does not have to wrestle with these kinds of questions. Kaplan writes (1998): "The teaching cases provided a discipline where we could visit each company for several days, interview a broad set of managers and engineers, collect data, write up our findings and share them with company managers."

\section{Insight 4: The importance of nuance in innovation ac- tion research}

According to Kaplan (1998), innovation action research requires the researcher (i.e., the consultant) to actively engage in helping the organization implement a new idea. In my case, this is done by using business environment analysis. Kaplan (1998) goes on to state that such an engagement will lead to the researcher not only learning more about the idea itself and how to improve it, but also how to implement it in organizations. In my case, this is a good description of how knowledge from different individual assignments could be used in other organizations. However, as the above insights show, Kaplan's model was developed under very special circumstances based on contact with large, well-established companies, where the company being researched was aware of the problem and welcomed Kaplan's projects. These circumstances cannot be considered normal within most consultancy work. Hence, a nuanced interpretation of Kaplan's model must be made and additional aspects must be incorporated into the model for it to be relevant for other types of action research projects, especially those with companies that are small, sometimes insecure, and that need to be patiently convinced to participate in a project.

\section{Conclusion}

So, what can action research learn from business environment analysis? First, there is the importance of where in the organization the person ordering a business environment analysis is, because this relates to the possible success of the project. It is not necessary to have access to top management, but it is important to be in the right context and have contacts with those who have the power to change. Second, it is also important to be able to identify both the knowledge structures and knowledge needs of the client, but at the same time be aware that the client usually needs help discovering these structures and needs; otherwise, there will not be a project. And, finally, action research should not be conducted only in large and confident companies; it can be useful even in the small, often cautious companies that make up the majority of the business community.

\section{About the Author}

Bengt Wahlström is a doctoral candidate at Mälardalen University in Sweden, where he holds a Licentiate of Philosophy degree. He is also a consultant and an author and has for decades been one of the leading experts in Scandinavia within innovation, business environment analysis, and future strategy. Every year, he meets with thousands of participants to hold discussions, seminars, and training programmes on these issues. His numerous books have sold over 60,000 copies, have won awards in Sweden and abroad, and have been translated into many languages. 


\section{Q\&A. What Can Action Research Learn from Business Environment Analysis? Bengt Wahlström}

\section{References}

Argyris, C., \& Schön, D. A. 1996. Organisational Learning II: Theory, Method and Practice. Reading, MA: Addison-Wesley.

Brunsson, N. 2006. The Organization of Hypocrisy: Talk, Decisions and Actions in Organizations. Malmö, Sweden: Liber

Coughlan, P., \& Coghlan, D. 2002. Action Research for Operations Management. International Journal of Operations \& Production Management, 22(2): 220-240.

https://doi.org/10.1108/01443570210417515

French, S. 2009. Action Research for Practising Managers. Journal of Management Development, 28(3): 187-204.

https://doi.org/10.1108/02621710910939596

Gummesson, E. 2000. Qualitative Methods in Management Research. Thousand Oaks, CA: SAGE.

Hamrefors, S. 2002. Den Uppmärksamma Organisationen. Från Business Intelligence till Intelligent Business. Lund, Sweden: Studentlitteratur.

Hoppe, M. 2009. Myten om det rationella flödet - En studie av hur organisatorisk ledning formas genom omvärldsanalys och underrättelsearbete $i$ kunskapsintensiva företagsmiljöer. Turku, Finland: Åbo Akademi University Press.

Johansson, A. W., \& Lindhult, E. 2008. Emancipation or Workability? Critical versus Pragmatic Scientific Orientation in Action Research. Action Research, 6(1): 95-115.

https://doi.org/10.1177/1476750307083713

Kaplan, R. S. 1998. Innovation Action Research: Creating New Management Theory and Practice. Journal of Management Accounting Research, 10: 89-118.

Lewin, K. 1946. Action Research and Minority Problems. Journal of Social Issues, 2(4): 34-46.

https://doi.org/10.1111/j.1540-4560.1946.tb02295.x

Pfeffer, J., \& Salancik, G. 2003. The External Control of Organizations: A Resource Dependency Perspective. Stanford, CA: Stanford University Books.

Porter, M. E. 1980. Competitive Strategy: Techniques for Analyzing Industries and Competitors. New York, NY: Free Press.

Rohrbeck, R., \& Gemünden, H. G. 2011. Corporate Foresight: Its Three Roles in Enhancing the Innovation Capacity. Technological Forecasting and Social Change, 78(2): 231-243.

http://doi.org/10.1016/j.techfore.2010.06.019

Taleb, N. N. 2008. The Black Swan: The Impact of the Highly Improbable. New York, NY: Penguin.

Keywords: action research, business environment analysis, consultancy, consultants, organizations 


\section{Academic Affiliations and Funding Acknowledgements}
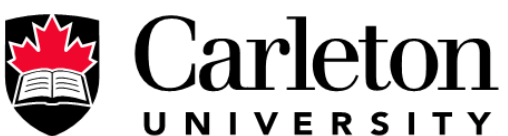

U N I V E R S I T Y

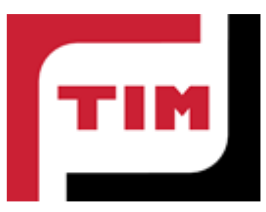

Technology Innovation Management (TIM; timprogram.ca) is an international master's level program at Carleton University in Ottawa, Canada. It leads to a Master of Applied Science (M.A.Sc.) degree, a Master of Engineering (M.Eng.) degree, or a Master of Entrepreneurship (M.Ent.) degree. The objective of this program is to train aspiring entrepreneurs on creating wealth at the early stages of company or opportunity lifecycles.

- The TIM Review is published in association with and receives partial funding from the TIM program. 